\title{
Effect of Millet Growth, N Sources and Previous Phosphorus Availability on the Efficiency of P Sources
}

\author{
Lucas de Ávila Silva ${ }^{1}$, Edson Marcio Mattiello ${ }^{1}$, Wedisson Oliveira Santos ${ }^{1}$, Reinaldo Bertola Cantarutti ${ }^{1}$ \\ \& Ivo Ribeiro da Silva ${ }^{1}$ \\ ${ }^{1}$ Department of Soil Science, Universidade Federal de Viçosa, Viçosa, Brazil \\ Correspondence: Lucas de Ávila Silva, Department of Plant Biology, Sector of Plant Physiology, Universidade \\ Federal de Viçosa (UFV), Av. P H Rolfs, Viçosa, Minas Gerais, 36570-000, Brazil. Tel: 55-313-899-2052. E-mail: \\ lucas.avila@ufv.br
}

Received: September 21, 2018

Accepted: October 29, 2018 Online Published: December 15, 2018

doi:10.5539/jas.v1 $1 \mathrm{n} 1 \mathrm{p} 360$

URL: https://doi.org/10.5539/jas.v11n1p360

The research is financed by Conselho Nacional de Desenvolvimento Cientifico e Tecnológico (CNPq) and Coordenação de Aperfeiçoamento de Pessoal de Nivel Superior (CAPES).

\begin{abstract}
The efficiency of phosphate fertilization has been a major challenge for tropical agriculture. Lately, cover plants better adapted to tropical conditions have allowed non-tillage in these areas. Our aim was to investigate the effects of soil and plant (millet) on the efficiency of different $\mathrm{P}$ sources combined with $\mathrm{N}$ sources in an oxisol with medium and low initial $\mathrm{P}$ availability. For this, rhizotubes filled with oxisol under different combinations of $\mathrm{P}$ and $\mathrm{N}$ source were exposed to the absence and presence of millet plant (Pennisetum glaucum L., Leeke). We characterized the soil before and after, as well the fertilizer sources and plants. There was no effect of medium or low initial $\mathrm{P}$ availability in the soil on the $\mathrm{P}$ recovery rate (PRR). $\mathrm{NH}_{4}{ }^{+}$was advantageous mainly combined with a soluble $\mathrm{P}$ source, increasing up to $40 \%$ the $\mathrm{P}$ recovery rate in relation to $\mathrm{NO}_{3}{ }^{-}$. Bayóvar phosphate rock (PR) had higher solubilization than Araxá PR, as well as a significant soil pH increase. Without plants, there was no significant correlation among the variables evaluated, evidencing the plant's role in dissolving less soluble $\mathrm{P}$ sources in an oxisol. Our findings suggest no effect of previous medium $\mathrm{P}$ availability on the $\mathrm{P}$ recovery rate regardless of phosphorus sources. In addition, an improvement in the $\mathrm{P}$ recovery rate when an ammoniacal source is used is observed when soluble phosphate fertilizers are used. Cover plants on oxisols are crucial for increasing the efficiency of phosphorus fertilizers and their plant availability over time.
\end{abstract}

Keywords: oxisol, millet, rhizosphere, phosphate rocks, nitrogen

\section{Introduction}

The consumption of $\mathrm{P}$ fertilizers has increased during recent decades in Brazil (Withers et al., 2018). About 5 million metric tons of phosphate $\left(\mathrm{P}_{2} \mathrm{O}_{5}\right)$ fertilizers are used each year in Brazilian agriculture (IPNI, 2016), making the country the fourth highest consumer of P fertilizer worldwide (Liebert, Griswold, \& Wilson III, 2015). In addition, the country is one of the largest consumers of natural phosphates in natura (IFA, 2013). However, P fertilization in tropical soils is known to be very inefficient (Roy et al., 2016), due to strong retention of phosphates by chemisorption on Fe- and Al-oxyhydroxides or precipitation into P-insoluble minerals (Novais \& Smyth, 1999; Parfitt, 1979).

The fates of the $\mathrm{P}$ added as fertilizer to crops are affected by several chemical properties of soils. In highly weathered soils, even large additions of $\mathrm{P}$ as fertilizer can be retained by soil particles, it being unavailable for plant uptake. In these conditions, recovery by crops of the P added can be less than $10 \%$ (Baligar \& Bennett, 1986; Santos et al., 2017). Soil management which keeps cover plants over time is capable of increasing $\mathrm{P}$ availability. In fact, covered soil has greater potential to improve the cycling of $\mathrm{P}$ in soil/plant systems (Calonego \& Rosolem, 2013), and also to prevent its fixation because of the organic matter dynamic of the soil (Guppy et al., 2005; Hunt et al., 2007). Brazil has extensive no-tillage areas, occupying about 32 million ha (FEBRAPDP/CONAB, 2012), in which the cultivation of millet (Pennisetum glaucum L.) has increased as a crop rotation due to its high biomass yield and robust root system, even under higher temperatures. 
The continued application of phosphate sources over time, and the use of cover plants better adapted to no-till farming can alter the dynamics of $P$ in soil to increase its plant availability (Teles et al., 2017). In fact, the availability of phosphate is affected by the root system architecture, and modifications to the rhizosphere chemical environment are of crucial importance for efficient management of phosphate fertilization (Dakora \& Phillips, 2002; Hinsinger, 2001; Hinsinger \& Gilkes, 1996). On the other hand, combinations of phosphate sources with ammoniacal sources have shown promise in calcareous soils (Hinsinger \& Gilkes, 1996; Jing, Rui, Zhang, Rengel, \& Shen, 2010) but with little information for tropical soils.

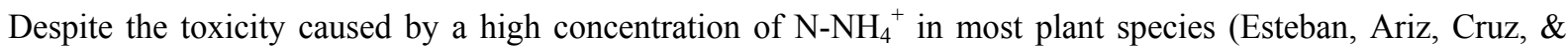
Moran, 2016; Kronzucker, Siddiqi, \& Glass, 1997), the majority of studies predict an increase in rhizospheric acidity and greater $\mathrm{P}$ uptake with $\mathrm{N}-\mathrm{NH}_{4}{ }^{+}$application, while results with $\mathrm{N}^{-\mathrm{NO}_{3}}{ }^{-}$application have shown the opposite trend (Hoffmann, Ladewig, Claassen, \& Jungk, 1994; Kant, Peng, \& Rothstein, 2011; Sarkar \& Wyn

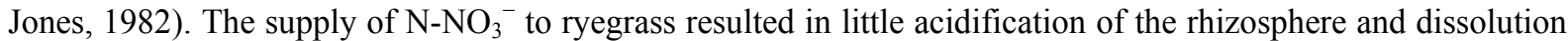
of about $20 \%$ of the PR added; however, when $\mathrm{N}^{-\mathrm{NH}_{4}}{ }^{+}$was supplied, there was a marked increase in rhizosphere acidity followed by an increase in rock dissolution (38\% of total P) (Hinsinger \& Gilkes, 1996). In maize cultivation in limestone soils, there was a significant improvement with the localized application of $\mathrm{P}$ combined with ammonium, favoring the growth and utilization of nutrients in the early stages, as well as root proliferation and acidification of the rhizosphere (Jing et al., 2010). Also in maize crop, ${\mathrm{N}-\mathrm{NH}_{4}}^{+}$induced acidification and optimized acid phosphatase activity excreted by roots, which improved root growth and $\mathrm{P}$ absorption of phytin and $\mathrm{NH}_{4}^{+}$(Ding et al., 2011).

Thus, the objective of this study was to investigate the effects on soil and plants of different $\mathrm{P}$ sources (with different reactivity) combined with $\mathrm{N}$ sources $\left(\mathrm{N}^{-\mathrm{NH}_{4}}{ }^{+}\right.$or $\left.\mathrm{N}^{-\mathrm{NO}_{3}}{ }^{-}\right)$on an oxisol with different initial $\mathrm{P}$ availability (low and medium).

\section{Material and Methods}

\subsection{Soil Sampling}

Soil samples were collected from a top layer $(5-20 \mathrm{~cm})$ of a Red-Yellow Oxisol in the municipality of Viçosa, Minas Gerais, Brazil. The soil was air-dried and passed through a sieve $(2 \mathrm{~mm})$ screen. Briefly, the soil had 63\% clay, pHwater 4.5, CEC $5.9 \mathrm{cmolc} \mathrm{dm}^{-3}, 5 \%$ base saturation, OM $17 \mathrm{~g} \mathrm{~kg}^{-1}, \mathrm{P}_{\text {Mehlich}}{ }^{-1} 1.2 \mathrm{mg} \mathrm{dm}^{-3}$, and P-remaining of $8 \mathrm{mg} \mathrm{dm}^{-3}$.

Aiming to increase the base saturation of the soil to $50 \%$, the soil samples were put into plastic bags, mixed with lime $\left(\mathrm{CaCO}_{3}: \mathrm{MgCO}_{3}\right.$ at a $\mathrm{Ca} / \mathrm{Mg}$ ratio of $\left.3.5: 1\right)$, wetted to $80 \%$ of the field capacity and maintained at that level for 30 days. After this time, part of the soil was mixed with triple superphosphate fertilizer (TSP, $150 \mathrm{mg} \mathrm{dm}^{-3} \mathrm{P}$ ) and incubated for 30 more days, in order to increase its P availability. After incubation with TSP, soil samples were air-dried and passed through a sieve $(2 \mathrm{~mm})$ screen for chemical characterization. The results showed small differences in $\mathrm{pH}$ (5.6 and 5.4), $\mathrm{Ca}\left(2.45\right.$ and $\left.2.35 \mathrm{cmol}_{\mathrm{c}} \mathrm{dm}^{-3}\right)$ and $\mathrm{Mg}\left(0.43\right.$ and $\left.0.6 \mathrm{cmol}_{\mathrm{c}} \mathrm{dm}^{-3}\right)$, but not P-resin $\left(0.07\right.$ and $\left.30 \mathrm{mg} \mathrm{dm}^{-3}\right)$, before and after their incubation with TSP, respectively.

\subsection{Characterization of $P$ and $N$ Sources}

We used as $\mathrm{P}$ sources TSP fertilizer $\left(44.0 \% \mathrm{P}_{2} \mathrm{O}_{5}\right)$, Bayóvar PR $\left(29.8 \%\right.$ of total $\mathrm{P}_{2} \mathrm{O}_{5}$ and $15.6 \%$ soluble $\mathrm{P}_{2} \mathrm{O}_{5}$ in $2 \%$ citric acid) and Araxá PR (30.7\% of total $\mathrm{P}_{2} \mathrm{O}_{5}$ and $4.6 \%$ soluble $\mathrm{P} 2 \mathrm{O} 5$ in $2 \%$ citric acid). As N-NH4 $4^{+}$source, we used (NH4) $)_{2} \mathrm{SO}_{4}$, and for N-NO3, $\mathrm{Mg}(\mathrm{NO} 3)_{2} \cdot 6 \mathrm{H}_{2} \mathrm{O}$ was used. For additional treatments, $9 \mathrm{mg} \mathrm{dm}^{-3}$ of dicyandiamide (DCD) was used as a nitrification inhibitor agent (Di \& Cameron, 2004).

\subsection{Trial Design and Conduct}

For confined root growth and greater soil exploration, cylindrical rhizotubes were made of chlorinated polyvinyl chloride (CPVC), $1.16 \mathrm{~cm}$ in diameter and $15.12 \mathrm{~cm}$ in length. The tubes were fixed onto a polyvinyl chloride (PVC) plate to be suspended. Each rhizotube was filled with $10 \mathrm{~cm}^{3}$ of soil sample. At the lower end of the rhizotubes, a $0.20-\mathrm{mm}$ nylon screen was glued, to contain the soil. Plant-free rhizotubes were used as a control treatment for comparison and better understand the plant's role.

The $\mathrm{P}$ and $\mathrm{N}$ fertilizers were previously mixed with each other and applied to the soil volume. A pre-germinated plant of millet (Pennisetum glaucum L., Leeke) was cultivated in each rhizotube for 46 days in a growth chamber, with a photoperiod of $12 \mathrm{~h}$, at $26 \pm 2{ }^{\circ} \mathrm{C}$ and radiance of $130 \pm 5 \mu \mathrm{mol} \mathrm{m} \mathrm{m}^{-2} \mathrm{~s}^{-1}$.

The treatments were arranged in a $2 \times 3 \times 4$ factorial scheme, with two initial $\mathrm{P}$ levels in the soil (low and medium); three P sources (Bayóvar PR, Araxá PR and TSP) at a dose of $300 \mathrm{mg} \mathrm{dm}^{-3}$ of P; four N sources: a control treatment $\left(0 \mathrm{mg} \mathrm{dm}{ }^{-3} \mathrm{~N}\right), 70 \mathrm{mg} \mathrm{dm}{ }^{-3}$ of $\mathrm{N}-\mathrm{NH}_{4}{ }^{+}\left[\left(\mathrm{NH}_{4}\right)_{2} \mathrm{SO}_{4}\right.$ without and with DCD $\left.)\right]$, and $\mathrm{N}^{-\mathrm{NO}_{3}}{ }^{-}\left[\left(\mathrm{Mg}\left(\mathrm{NO}_{3}\right)_{2} \cdot 6 \mathrm{H}_{2} \mathrm{O}\right)\right]$. 


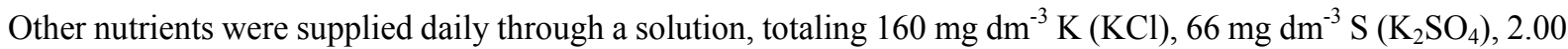
$\mathrm{mg} \mathrm{dm}{ }^{-3} \mathrm{Zn}\left(\mathrm{ZnCl}_{2}\right), 1.83 \mathrm{mg} \mathrm{dm}{ }^{-3} \mathrm{Mn}\left(\mathrm{MnCl}_{2} \cdot 4 \mathrm{H}_{2} \mathrm{O}\right), 0.78 \mathrm{mg} \mathrm{dm}{ }^{-3} \mathrm{Fe}\left(\mathrm{FeCl}_{3} \cdot 6 \mathrm{H}_{2} \mathrm{O}\right), 0.67 \mathrm{mg} \mathrm{dm}{ }^{-3} \mathrm{Cu}$ $\left(\mathrm{CuCl}_{2} \cdot 2 \mathrm{H}_{2} \mathrm{O}\right), 0.40 \mathrm{mg} \mathrm{dm}^{-3} \mathrm{~B}\left(\mathrm{H}_{3} \mathrm{BO}_{3}\right)$ and $0.08 \mathrm{mg} \mathrm{dm}^{-3} \mathrm{Mo}\left(\left(\mathrm{NH}_{4}\right)_{6} \mathrm{Mo}_{7} \mathrm{O}_{24} \cdot 4 \mathrm{H}_{2} \mathrm{O}\right)$.

\subsection{Sampling and Chemical Analysis}

The plants and soil samples were collected 46 days after transplanting. The soil was separated from the roots, homogenized, air-dried and sieved ( $2 \mathrm{~mm}$ sieve). Samples of shoots and roots were oven-dried at $65 \pm 2{ }^{\circ} \mathrm{C}$ for 72 $\mathrm{h}$ until constant mass, weighed and milled for chemical analysis. We kept the original soil samples, which were considered as references $\left(T_{0}\right)$.

The plant samples were mineralized in an open-vessel digestion system using a nitric-perchloric solution $(4: 1 \mathrm{v}$ $\mathrm{v}^{-1}$ ) (Miller, 1998). The $\mathrm{N}$ content was measured by the Kjeldahl method, $\mathrm{P}$ by molecular absorption spectroscopy, and $\mathrm{Ca}$ and $\mathrm{Mg}$ by atomic absorption spectroscopy.

The soil samples were analyzed for $\mathrm{pH}$ in water, and available content of $\mathrm{Ca}^{2+}, \mathrm{Mg}^{2+}$ (EMBRAPA, 1997), $\mathrm{NH}_{4}^{+}$ (Kempers \& Zweers, 1986), $\mathrm{NO}_{3}^{-}$(Yang, Kim, Skogley, \& Schaff, 1998) and P (Raij, Quaggio, \& Silva, 1986).

\subsection{Data and Statistical Analysis}

The total P content was obtained from the product of dry matter mass and its concentration in the tissues (shoot or root) of the millet. The P recovery rate (PRR) by plants was calculated by Equation 1:

$$
P R R=[(A M-A M C) /(A A P)] \times 100
$$

where,

AM: amount of $\mathrm{P}$ accumulated in the plant tissue when P fertilizers were used; AMC: amount of P accumulated in the plant tissue for the control treatment; AAP: amount of added $\mathrm{P}$ as fertilizer, corresponding to $300 \mathrm{mg} \mathrm{dm}^{-3}$ $P$ from the different sources.

Solubilization of the PR was evaluated by the exchangeable Ca content in the soil and Ca concentration in the plant tissues (adapted from Bolan \& Hedley, 1990) by Equation 2:

$$
\left.P R \text { solubilization }=\triangle C a=\left[\left(C a_{T 46}+C a_{\text {plant }}\right)-C a_{T 0}\right)\right]
$$

where,

$\mathrm{Ca}_{\mathrm{T46}}$ : quantity of $\mathrm{Ca}$ in the volume of soil used at the end of 46 days of millet cultivation (mg rhizotube ${ }^{-1}$ ); $\mathrm{Ca}_{\text {plant }}$ : $\mathrm{Ca}$ content in the plant at the end of 46 days of millet cultivation $\left(\mathrm{mg}\right.$ plant $\left.{ }^{-1}\right) ; \mathrm{Ca}_{\mathrm{T} 0}$ : quantity of $\mathrm{Ca}$ in the volume of soil used in $\mathrm{T}_{0}\left(\mathrm{mg}\right.$ rhizotube $\left.{ }^{-1}\right)$.

Initially, the normality of the errors and the homogeneity of variance were verified. Nonconforming data were transformed according to a Box and Cox approach (Box \& Cox, 1964). Statistical analysis was carried out by three-way analysis of variance (ANOVA) using a general linear model through GENES and R software (Cruz, 2013; R Development Core Team, 2016). The effects of the P sources with each combination of $\mathrm{N}$ and within each P level were evaluated by the Duncan test at 5\% significance. Pearson's correlations were also calculated. Analyses were performed using Sigma Stat software v.2.0 (SPSS Inc., Chicago, IL, USA) and GraphPad Prism 7 (GraphPad Prism version 7 for Windows, GraphPad Software, La Jolla, California, USA). In addition, we applied the false discovery rate (FDR)-controlling method for each correlation p-value (Benjamini \& Hochberg, 1995), using an R script in Rbio software (www.biometria.ufv.br) (Bhering, 2017; R Development Core Team, 2016).

\section{Results}

\subsection{P Recovery Rate and Biomass}

By decomposing the factorial, we can observe in detail the effect of the combinations of $\mathrm{P}$ and $\mathrm{N}$ sources on the $\mathrm{P}$ recovery rate, PRR (Figure 1). There were no significant differences in PRR by millet contrasting the initial $\mathrm{P}$ availability; nevertheless, the performance of the $\mathrm{P}$ or $\mathrm{N}$ sources was affected by it. PRR followed the solubility of the P sources. TSP provided higher values, followed by Bayóvar PR and Araxá PR. Interactions between TSP and ammonium sulfate promoted a higher PRR than other treatment combinations. The combination of TSP with the nitric source (TSP+N) provided a PRR similar to that for no N supply. In addition, when TSP was combined with $\mathrm{N}_{-} \mathrm{NO}_{3}{ }^{-}$, the PRR was $40 \%$ lower than when it was associated with the ammoniacal nitrogen source.

For the PRs (Bayóvar PR and Araxá PR), there were no differences in terms of PRR for their combinations with the nitrogen sources. However, one treatment that drew attention was Bayóvar PR combined with ammonium 
sulfate plus DCD in soil with medium initial P availability. This treatment was the only one that differed from the control.
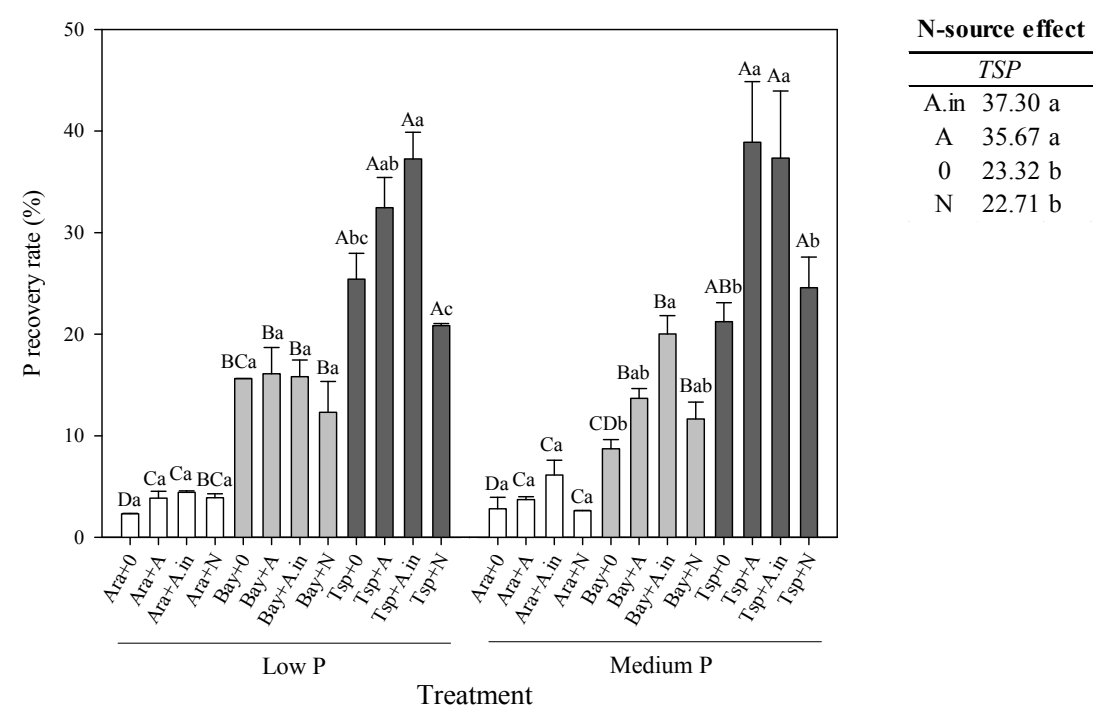

Figure 1. P recovery rate (PRR) by millet grown under 24 different combinations of $\mathrm{P}$ and $\mathrm{N}$ sources. The factorial "P source $\times \mathrm{N}$ source" was splitted and shown in the figure. $\mathrm{P}$ sources: Ara $=$ Araxá PR, Bay = Bayóvar

$\mathrm{PR}, \mathrm{TSP}=$ triple superphosphate. Nitrogen sources: $0=$ non-application of $\mathrm{N}, \mathrm{A}=$ ammonium sulfate, $\mathrm{A} . \mathrm{in}=$ ammonium sulfate with dicyandiamide (DCD) - a nitrification inhibitor agent, $\mathrm{N}=$ magnesium nitrate.

Uppercase letters compare the means between the $\mathrm{P}$ sources within each $\mathrm{N}$ source. Lowercase letters compare the N sources within each P source. Means were compared by the Duncan test at $5 \%$ significance

There were no differences in shoot or root production by millet when the initial $\mathrm{P}$ availability was low or medium (Figure 2). However, in soil with low initial P availability, the ammoniacal source plus DCD provided greater shoot dry weight production compared to that with the nitric source, but equivalent to that with ammonium without DCD. In general, the similar values of shoot and root dry weight suggest that the greatest PRR was mainly due to an increase in the P content in plant tissues, and not to the increase in biomass.

The combination of Araxá PR with the ammoniacal source plus DCD, when the initial P availability was low, significantly increased its performance as fertilizer. This combination was as efficient as other combinations in terms of shoot dry weight production by millet (Figure 2). 

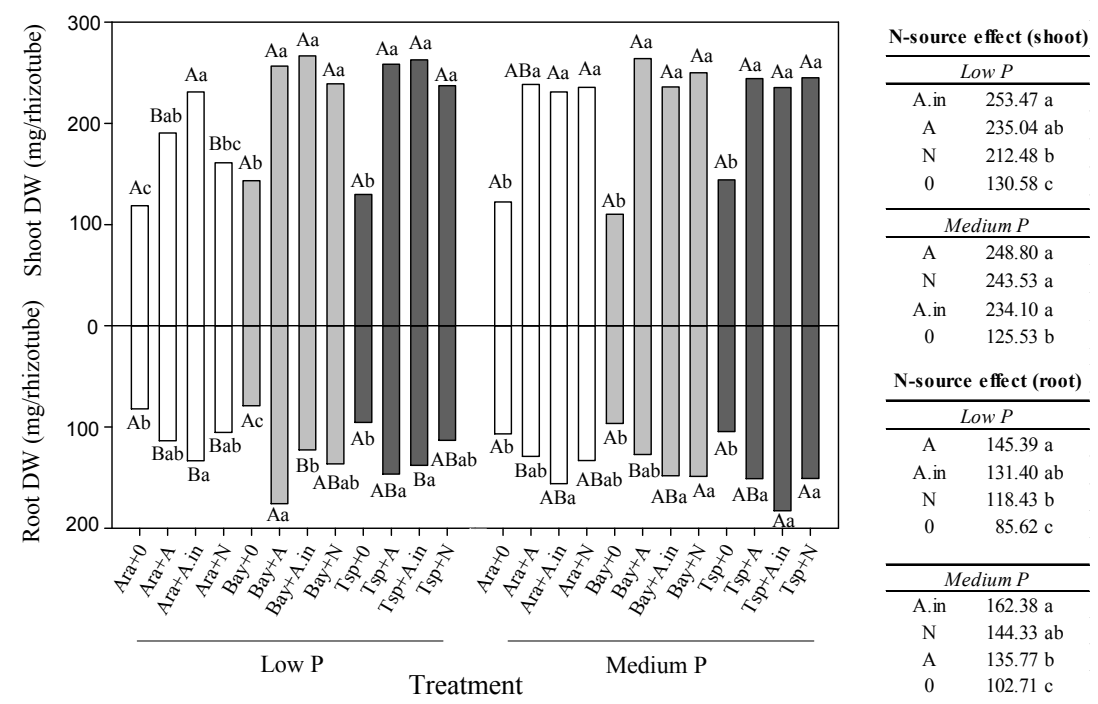

Figure 2. Shoot and root dry weight of millet grown under 24 different combinations of $\mathrm{P}$ and $\mathrm{N}$ sources, at low and medium initial $\mathrm{P}$ level. The factorial " $\mathrm{P}$ source $\times \mathrm{N}$ source" was splitted and shown in the figure. $\mathrm{P}$ sources:

$\mathrm{Ara}=$ Araxá $\mathrm{PR}, \mathrm{Bay}=$ Bayóvar PR, TSP $=$ triple superphosphate. $\mathrm{N}$ sources: $0=$ non-application of $\mathrm{N}, \mathrm{A}=$ ammonium sulfate, $\mathrm{A}$.in = ammonium sulfate with dicyandiamide $(\mathrm{DCD})-$ a nitrification inhibitor agent, $\mathrm{N}=$ magnesium nitrate. Uppercase letters compare the mean between the P sources within each $\mathrm{N}$ source. Lowercase letters compare the $\mathrm{N}$ sources within each $\mathrm{P}$ source. Means were compared by the Duncan test at $5 \%$ significance.

The table on the right shows the interaction of "N source $\times$ initial $\mathrm{P}$ level" in the shoot and root dry weight

\subsection{Solubilization of Phosphate Rocks $(\Delta C a)$ and $P$ Variation in the Rhizospheres $(\Delta P)$}

Solubilization of the PR was not affected by the initial P availability in soil (Figure 3). For both P availabilities, Bayóvar PR was more soluble than Araxá PR. In general, when $\mathrm{N}$ was not supplied, we observed smaller $\Delta \mathrm{Ca}$ than in its presence, demonstrating greater solubilization of PRs when $\mathrm{N}$ was used. In soil with low initial $\mathrm{P}$ availability, the combination of Araxá PR with the ammoniacal source and DCD provided a greater $\triangle \mathrm{Ca}$ in relation to the combination with the nitric source. Interestingly, in soil with medium initial P availability, there were higher $\triangle \mathrm{Ca}$ when Araxá PR was combined with the nitrate source. Unlike that of Araxá PR, the solubilization of Bayóvar PR was affected by the $\mathrm{N}$ supply only in soil with low initial P availability, without differences between the $\mathrm{N}$ sources.

$\Delta \mathrm{P}$ is a variable complementary to $\Delta \mathrm{Ca}$ to predict the solubilization of $\mathrm{PRs}$ in soil, but it is less predictive (Figure 4). Indeed, in oxisols, the solubilization of PRs does not always correlate with the plant $P$ availability because of the fast kinetics of $\mathrm{P}$ chemisorption on $\mathrm{Fe}$ - and $\mathrm{Al}$-oxyhydroxides compared to its release rate from PRs. The $\Delta \mathrm{P}$ value was higher in soils with medium $\mathrm{P}$ availability. Bayóvar PR provided a greater amount of $\mathrm{P}$ in the soil in relation to Araxá PR, about 2.5-fold more. There was a significant effect of the combination of Bayóvar PR and the ammoniacal source. By decomposing the factorial, we observed that this effect was most pronounced in soil with medium initial $\mathrm{P}$ availability.

\subsection{Multivariate Analysis}

Principal component analysis (PCA) indicated a separation of the combinations of the $\mathrm{P}$ and $\mathrm{N}$ sources (Figure 5). The first major component (PC1) explained $52.1 \%$ of the variation. The main loading factors that contributed to the separation in PC1 were P content in roots, PRR, and P and Ca content in shoots. 


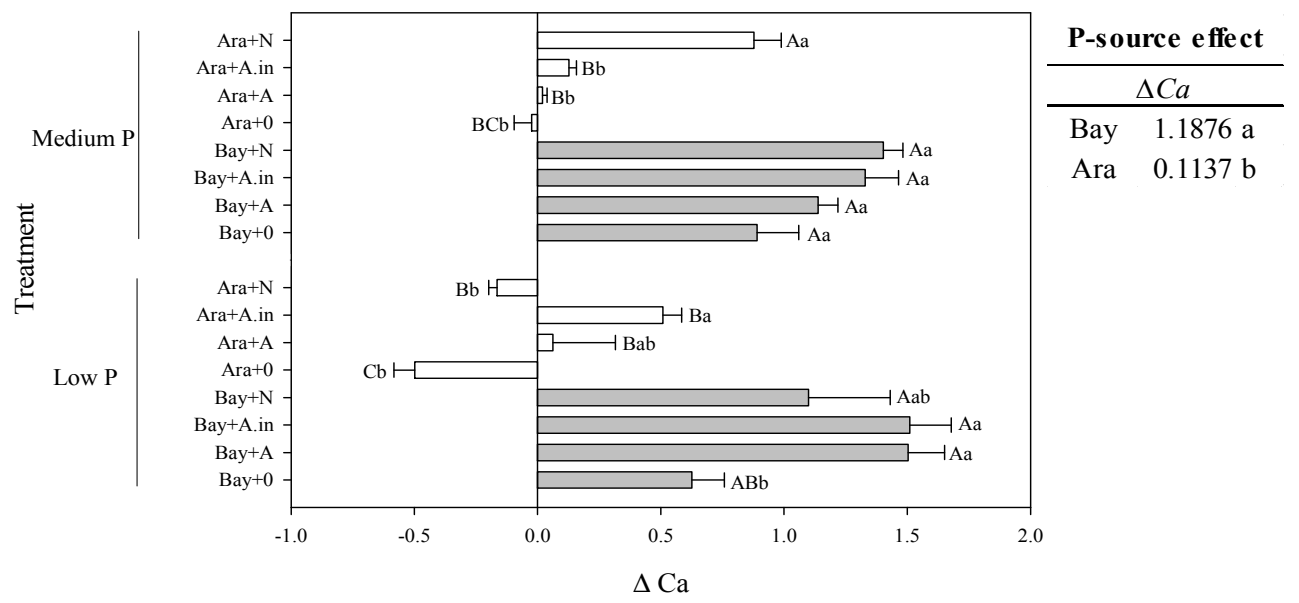

Figure 3. $\Delta \mathrm{Ca}$ of millet rhizosphere soil cultivated under 16 different combinations of $\mathrm{PR}$ and $\mathrm{N}$ sources, at low and medium $\mathrm{P}$ level. The factorial "P source $\times \mathrm{N}$ source" was splitted and shown in the figure. $\mathrm{P}$ sources: Ara $=$

Araxá PR, Bay $=$ Bayóvar PR, TSP $=$ triple superphosphate. $\mathrm{N}$ sources: $0=$ non-application of $\mathrm{N}, \mathrm{A}=$ ammonium sulfate, A.in = ammonium sulfate with dicyandiamide $(D C D)-$ a nitrification inhibitor agent, $\mathrm{N}=$ magnesium nitrate. Uppercase letters compare the mean between the P sources within each $\mathrm{N}$ source. Lowercase letters compare the $\mathrm{N}$ sources within each P source. Means were compared by the Duncan test at $5 \%$ significance. The table on the right shows the interaction of P-source effect in $\Delta \mathrm{Ca}$

(Figure 5B, Table A1). The best treatments in relation to the variables evaluated are to the right of the $y$-axis in Figure 5A. The most promising combinations included TSP fertilizer as the $\mathrm{P}$ source, which is highly water-soluble. In soil with low initial P availability, the effectiveness of TSP when it was associated with ammonium sulfate was highlighted. Overall, Bayóvar PR and Araxá PR were less effective than TSP, respectively. Apparently, when considering all variables analyzed, for TSP and Bayóvar PR, combination with the ammoniacal source was more effective when the initial P availability was low. Under medium initial $\mathrm{P}$ availability, the $\mathrm{N}$ supply was important but there were few differences between the $\mathrm{N}$ sources. This same behavior was presented for Araxá PR; however, all combinations are on the left side of the $y$-axis and point out the unfeasibility of using this source in natura.

The second component (PC2), which explained $21.4 \%$ of the variation, separated the combinations mainly in relation to acidification or alkalization (Table A1). Most of the combinations with Bayóvar PR were near or below the $x$-axis, which showed the alkalization power of this $\mathrm{P}$ source, mainly because it contains calcium carbonate. Combinations with the absence of $\mathrm{N}$ or when the nitric source was used also favored alkalization of the rhizosphere (Figure A1).

To complement the quantitative description of the patterns presented by the treatments, a correlation analysis was performed involving the factors responsible for the separation of treatments in PCA. For that, all the data points were run through a pairwise correlation analysis (Figure 6A). Out of 55 possible pairs analyzed, 29 resulted in significant correlations $(p \leq 0.05)$. Of these, after FDR correction, 25 resulted in significant correlations (Figure 6B). In general, the evaluation parameters of $\mathrm{P}$ and $\mathrm{Ca}$ were shown to be highly correlated. Describing some more striking correlations, PRR correlated with the total P and Ca content in shoots (P shoots and $\mathrm{Ca}$ shoots), total amount of $\mathrm{P}$ in roots (P roots) and with the amount of available $\mathrm{P}$ in soil (P res). The Ca content in soil (Ca soil) correlated with $\mathrm{P}$ res and $\mathrm{P}$ content in roots. In fact, these results are expected given that both elements come from the P sources. 


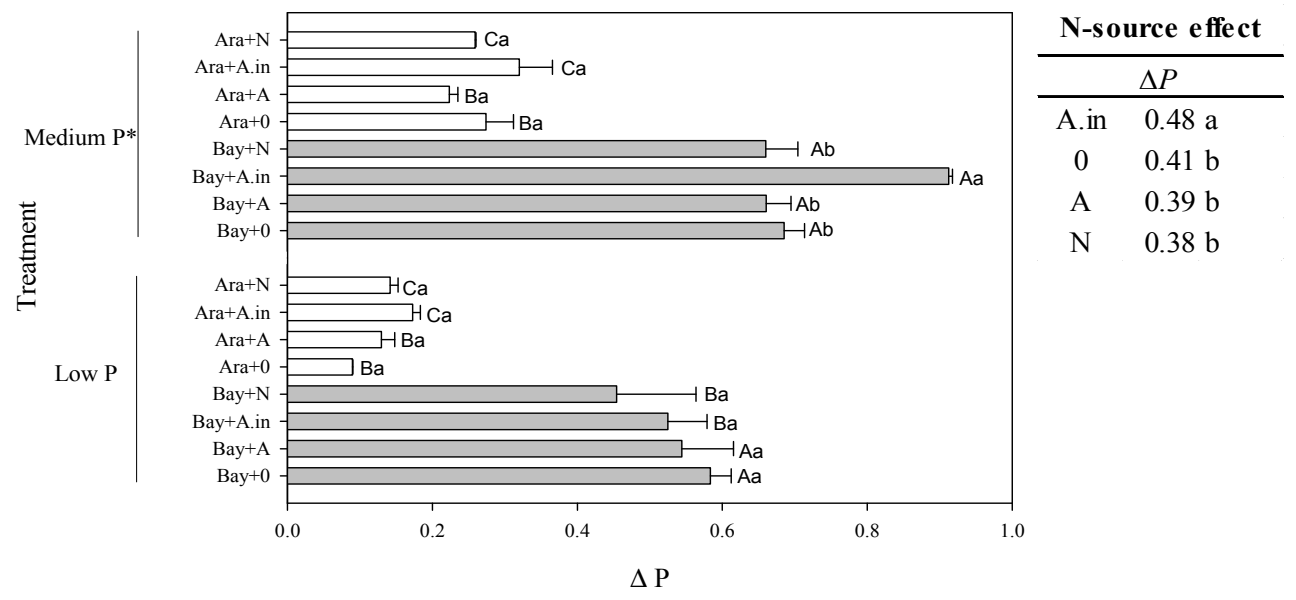

Figure 4. $\Delta \mathrm{P}$ of millet rhizosphere soil cultivated under 16 different combinations of $\mathrm{PR}$ and $\mathrm{N}$ sources, at low and medium initial $\mathrm{P}$ level. The asterisk indicates that $\Delta \mathrm{P}$ was greater in plants grown in soil with a medium initial P level (test F). The factorial "P source $\times \mathrm{N}$ source" was splitted and shown in the figure. $\mathrm{P}$ sources: Ara $=$

Araxá PR, Bay = Bayóvar PR, TSP = triple superphosphate. $\mathrm{N}$ sources: $0=$ non-application of $\mathrm{N}, \mathrm{A}=$ ammonium sulfate, $\mathrm{A} . \mathrm{in}=$ ammonium sulfate with dicyandiamide (DCD) - a nitrification inhibitor agent, $\mathrm{N}=$ magnesium nitrate. Uppercase letters compare the mean between the P sources within each $\mathrm{N}$ source. Lowercase letters compare the $\mathrm{N}$ sources within each $\mathrm{P}$ source. Means were compared by the Duncan test at 5\% significance.

The table on the right shows the effect of $\mathrm{N}$ source on $\Delta \mathrm{P}$

\subsection{Plant Effect and Nitrification}

On cultivated soil, the use of Bayóvar PR promoted greater alkalization of the rhizospheric environment, but Araxá PR led to acidification (Figure A1). Nitrogen sources also had significant effects on $\mathrm{pH}$ change in the rhizosphere. In this case, for soil with low and medium initial $\mathrm{P}$ availability, there was greater alkalization for combinations of Bayóvar PR and nitric source, followed by those with the absence of $\mathrm{N}$. There was acidification when the ammoniacal source was supplied (Figure A1). Millet subjected to the exclusive ammonium supply did not show toxicity symptoms, including no reduction in growth.

To better understand the factors involved in the best use of $\mathrm{P}$ by millet, a soil mirror experiment without the presence of plants was also carried out for comparison, aiming to demonstrate the effects of the plants' presence. Ammonium was not detected in soils in the presence of plants, indicating that the plants consumed all the added $\mathrm{N}$ source since in the absence of plants there was a coherent quantification of this cation (Figure A2). There were also no significant differences in the amount of nitrate detected; in addition, a small basal amount was found in cultivated soil (Figure A3). Also, for nitrate, there was coherent detection in soil without the presence of plants (Figure A2). These data indicate that there were no large nitrification rates, so that most of the ammonium applied to the soil was maintained. This fact also allows the inference that the $\mathrm{pH}$ alterations in soil observed under plant cultivation were related to ammoniacal source uptake and not to the nitrification process.

Without the presence of plants, there were no significant correlations among the variables evaluated in the soil (Figure A4) (except for $\mathrm{pH}$ and $\Delta \mathrm{pH}$ ). In these conditions, there was also smaller $\Delta \mathrm{Ca}$ and $\Delta \mathrm{P}$ in the soil (Figures A5 and A6), evidencing the importance of the plant component in the system to modulate the processes of dissolving less soluble P sources in an oxisol.

\section{Discussion}

The efficiency of the phosphate sources as fertilizers was shown to be dependent on intrinsic characteristics of the $\mathrm{P}$ and $\mathrm{N}$ sources and the plant itself. Because a significant area of cultivated tropical soils have medium $\mathrm{P}$ availability, due to recurrent $\mathrm{P}$ fertilizer application over time, we also tested combinations of $\mathrm{P}$ and $\mathrm{N}$ sources considering this current scenario. However, there were no differences in PRR on altering the initial P availability of the oxisol, evidencing that highly weathered soils have high P chemisorption capacity (Novais \& Smyth, 1999; Parfitt, 1979), keeping a low P concentration in soil solution (Novais \& Smyth, 1999). In these conditions, the diffusive flux of $\mathrm{P}$ in the soil is low, decreasing its availability for plant growth (Schachtman, Reid, \& Ayling, 1998). 

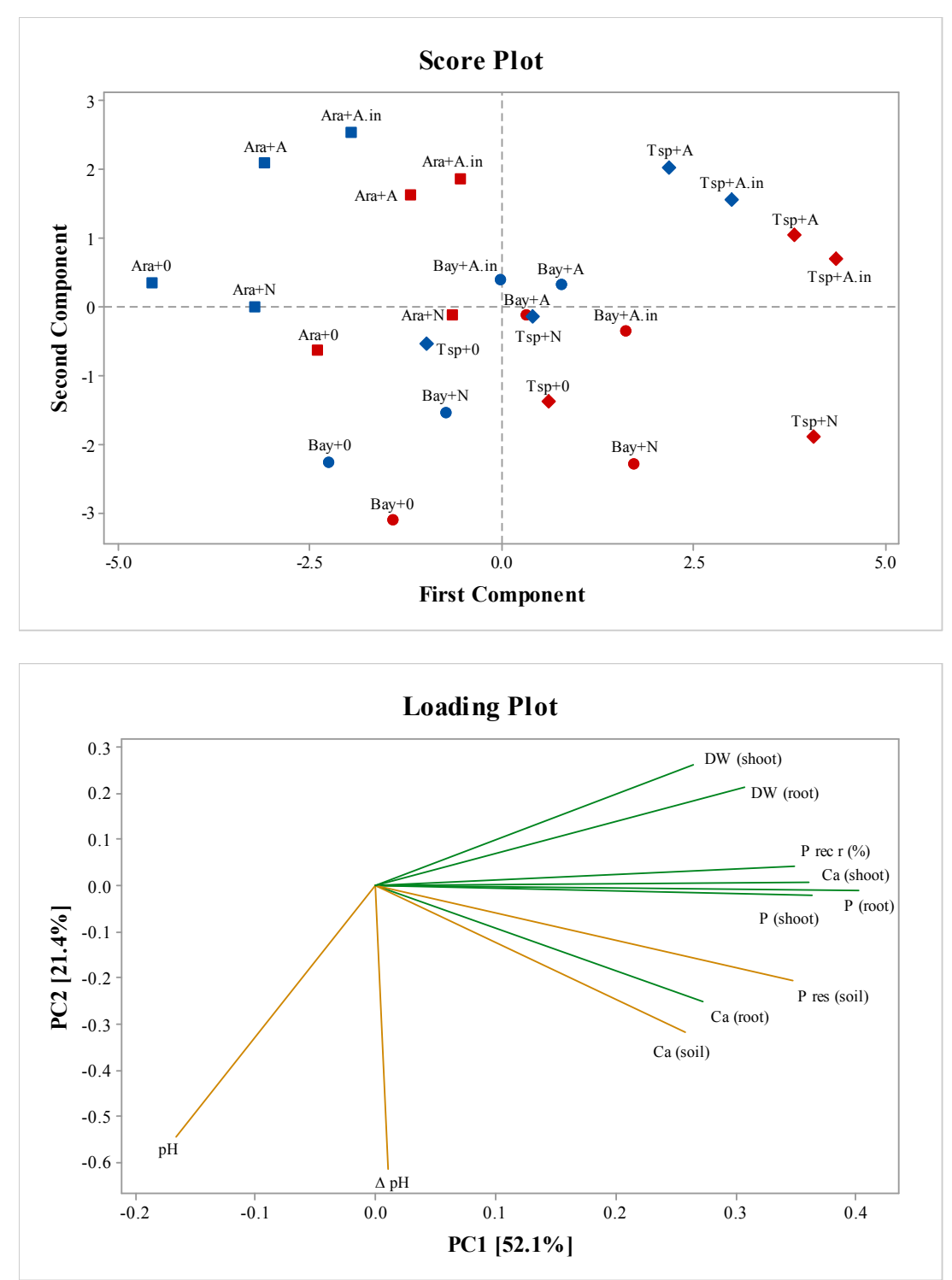

Figure 5. Principal component analysis score plot derived from data of millet plants supplied with different combinations of $\mathrm{P}$ and $\mathrm{N}$ sources. The blue and red colors indicate plants grown under low and medium $\mathrm{P}$ initial availability in an oxisol, respectively. The P fertilizers are presented by different shapes: TSP (diamond), Bayóvar PR (circle) and Araxá PR (square). The combinations of P and N sources are indicated in the graph. In the loading plot, the direction and length of the lines are directly proportional to their importance in separating groups. PC1, principal component 1, explaining $52.1 \%$ of the variance; PC2, principal component 2 , explaining

$21.4 \%$ of the variance. Abbreviations: dry weight of root (DW (root)), dry weight of shoot (DW (shoot)), available $\mathrm{P}$ by the anionic resin extractor (P res), P recovery rate (P rec $\mathrm{r}(\%)$ ) and difference in soil $\mathrm{pH}$ before and after the experiment $(\Delta \mathrm{pH})$ 

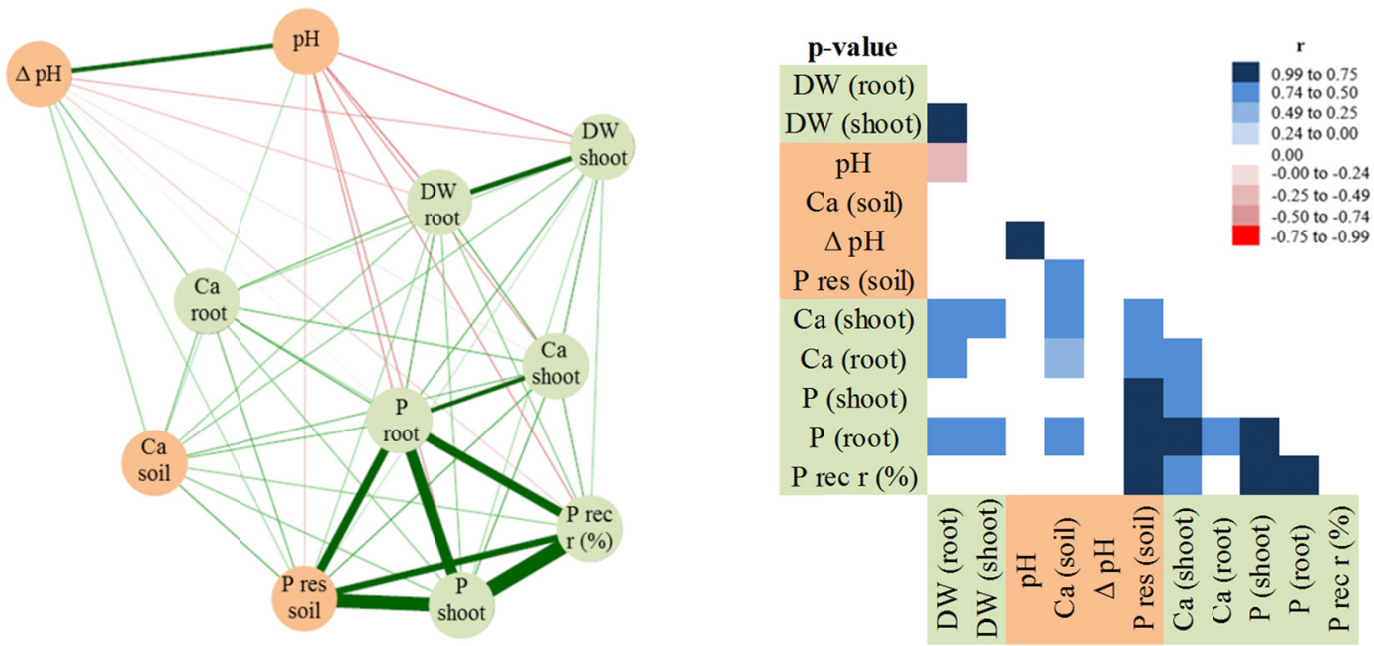

Figure 6. (A) Correlation network between variables derived from data of millet plants supplied with different combinations of $\mathrm{P}$ and $\mathrm{N}$ sources. Red and green lines represent negative and positive correlations, respectively. Line width is proportional to the strength of the correlation. (B) Heat map of correlations between soil and plant parameters of 24 combinations of $\mathrm{P}$ (Bayóvar PR, Araxá PR and TSP) and $\mathrm{N}\left(\mathrm{N}-\mathrm{NH}_{4}{ }^{+}\right.$and $\mathrm{N}^{-\mathrm{NO}_{3}}{ }^{-}$) sources under different initial P levels (P-low and P-medium). Each square represents significant correlation between the parameters heading the column with the parameters heading the row. Correlation coefficients and significances were calculated by Pearson correlations $(p<0.05)$. Blue and red squares represent positive and negative correlations, respectively; in addition, the correlation data were corrected by base FDR

(Benjamini \& Hochberg, 1995)

Some studies have shown positive results when $\mathrm{P}$ is supplied by combining soluble sources with PR, for development of root systems, which promotes greater agronomic efficiency in PR use (Chien, Prochnow, Tu, \& Snyder, 2011; Prochnow, Chien, Carmona, \& Henao, 2004). In our development, there was better P availability in the soil when the initial P availability was at a medium level, but it did not lead to a greater PRR by plants. In addition, we can observe that PRR was strongly related to the solubility of P sources. TSP promoted higher PRRs, followed by Bayóvar PR and Araxá PR. PR of sedimentary origin (Bayóvar PR) is more reactive than that from igneous deposit (Araxá PR) because it contains more poorly crystalline apatites (Santos et al., 2016), leading it to release P into soil solution at higher rates. In addition, in the PCA approach, PC1 clearly reflected the contrasting effect of P-source solubility on the factors evaluated (Figure 5).

The combination of a soluble phosphate fertilizer (TSP) with $\mathrm{N}_{-} \mathrm{NH}_{4}{ }^{+}$allowed a higher PRR than the combination with $\mathrm{N}^{-\mathrm{NO}_{3}}{ }^{-}$, regardless of the initial $\mathrm{P}$ availability. Two factors possibly explain this response: greater $\mathrm{P}$ uptake and greater $\mathrm{P}$ diffusion in the presence of ammonium. Greater $\mathrm{P}$ uptake in the presence of ammonium has already been observed in several works, especially considering calcareous and alkaline soils (Jing et al., 2010; Ortas, Harris, \& Rowell, 1996; Wang, Guppy, Watson, Sale, \& Tang, 2011). An improvement of the PRR for ammoniacal source use was recently reported by Valadares et al. (2017), but only when soluble phosphate fertilizers were used.

Using nutrient solution, it was verified that $\mathrm{P}$ uptake can be stimulated in rice plants by supplying them with $\mathrm{NH}_{4}{ }^{+}$because of the greater activity of $\mathrm{H}^{+}$-ATPase in the plasma membrane of the root cells (Zeng et al., 2012). In addition, when verifying that $\mathrm{P}$ accumulation increased with decreasing $\mathrm{NO}_{3}{ }^{-}$supply, it has been proposed that there is an antagonistic genetic interaction of $\mathrm{P}$ with nitrate but not with ammonium in Arabidopsis (Kant et al., 2011). On the other hand, another factor that may have contributed to the better performance of the P-soluble source is the greater diffusion of orthophosphate in water when ammonium ions are present (Villani et al., 1998). This effect may have been insignificant for PRs since the solubilization rate may not allow P availability coincident with $\mathrm{N}$ uptake.

The small values of $\mathrm{N}_{-} \mathrm{NH}_{4}{ }^{+}$and $\mathrm{N}_{-} \mathrm{NO}_{3}{ }^{-}$in soil under millet showed the consumption of a large part of the applied $\mathrm{N}$ source. Millet has shown to be tolerant to the use of $\mathrm{N}_{-} \mathrm{NH}_{4}{ }^{+}$. Not all plant species are tolerant to the exclusive ammonium supply and its effects on plant and soil (Gweyi-Onyango, Neumann, \& Romheld, 2005; Kronzucker et al., 1997; Sarasketa, González-Moro, González-Murua, \& Marino, 2014). Possibly, the tolerance of millet to these conditions is due to its tropical origin and its having gone through few processes of crop 
breeding (Bloom, Jackson, \& Smart, 1993; Kronzucker, Britto, Davenport, \& Tester, 2001). In this context, we can highlight root system maintenance, considering the importance of this factor in the efficiency of $\mathrm{P}$ acquisition (Lambers, Shane, Cramer, Pearse, \& Veneklaas, 2006). It is known that ammonium modifies the root system by inhibiting root elongation, stimulating lateral root branching or swelling root hairs (Liu \& von Wirén, 2017).

In consequence of the $\mathrm{N}_{-} \mathrm{NH}_{4}{ }^{+}$or $\mathrm{N}-\mathrm{NO}_{3}{ }^{-}$supply, the rhizosphere $\mathrm{pH}$ was altered in maintaining cellular electrical neutrality (Dakora \& Phillips, 2002; Gahoonia, Claassen, \& Jungk, 1992; Haynes, 1990; Philippe Hinsinger, Plassard, Tang, \& Jaillard, 2003). Greater buffering of $\mathrm{pH}$ and exchangeable $\mathrm{Ca}^{2+}$ was observed when Bayóvar PR was supplied because it is from a marine sedimentary deposit, where its occurrence is associated with calcium carbonate ores. In PCA analysis, PC2 explained $21.4 \%$ of the variance, and the pH alteration caused by the combinations was the major component (Figure 5).

We used non-plant rhizotubes to verify if the nitrification process could contribute to the $\mathrm{pH}$ change in the rhizosphere. With this, we verified that nitrification did not significantly affect the rhizospheric acidity, supposedly due to the low rates achieved. Other studies also report a low nitrification rate in soil (Khalil, Boeckx, Rosenani, \& Cleemput, 2001; Zhao, Cai, \& Xu, 2007).

In the absence of plants, the factors evaluated had much lower positive correlations and fewer soil alterations (Figure A4), and poor solubilization of the PRs. These results demonstrate the importance of the presence of plants in the soil in promoting conditions for solubilizing PRs or increasing the plant P availability, including their effects such as $\mathrm{Ca}$ and $\mathrm{P}$ drainage, rhizosphere acidification and stimulating the biological activity that can contribute to $\mathrm{P}$ solubilization and cycling.

\section{Conclusion}

This study shows that there is no effect of previous medium $\mathrm{P}$ availability on PRR regardless of phosphorus source used in oxisols. In addition, it provides evidence that the presence of cover plants on oxisols is crucial for increasing the efficiency of phosphorus fertilizers and their plant availability over time. Improvement of PRR when an ammoniacal source is used is observed when soluble phosphate fertilizers are used. Millet is highlighted as a useful crop for promoting solubilization of PRs, with the advantage of being a high biomass-yielding plant promoting efficient cover of the soil surface.

\section{Acknowledgements}

The authors would like to thank the Conselho Nacional de Desenvolvimento Científico e Tecnológico (CNPq) and Coordenação de Aperfeiçoamento de Pessoal de Nível Superior (CAPES) for the financial support and scholarships. All the authors thank Paulo Rodrigues and Írio Fernando de Freitas for the lab support.

\section{References}

Baligar, V. C., \& Bennett, O. L. (1986). Outlook on fertilizer use efficiency in the tropics. Fertilizer Research, 10(1), 83-96. https://doi.org/10.1007/BF01073907

Benjamini, Y., \& Hochberg, Y. (1995). Controlling the false discovery rate: A practical and powerful approach to multiple testing. Journal of the Royal Statistical Society, 57, 289-300.

Bhering, L. L. (2017). Rbio: A tool for biometric and statistical analysis using the R platform. Crop Breeding and Applied Biotechnology, 17, 187-190. https://doi.org/10.1590/1984-70332017v17n2s29

Bloom, A. J., Jackson, L. E., \& Smart, D. R. (1993). Root growth as a function of ammonium and nitrate in the root zone. Plant, Cell \& Environment, 16(2), 199-206. https://doi.org/10.1111/j.1365-3040.1993.tb00861.x

Bolan, N. S., \& Hedley, M. J. (1990). Dissolution of phosphate rocks in soils. 2. Effect of pH on the dissolution and plant availability of phosphate rock in soil with $\mathrm{pH}$ dependent charge. Fertilizer Research, 24(3), 125-134. https://doi.org/10.1007/BF01073580

Box, G. E. P., \& Cox, D. R. (1964). An analysis of transformations. Journal of the Royal Statistical Society. Series B Methodological, 211-252. https://doi.org/10.2307/2287791

Calonego, J. C., \& Rosolem, C. A. (2013). Phosphorus and potassium balance in a corn-soybean rotation under no-till and chiseling. Nutrient Cycling in Agroecosystems, 96(1), 123-131. https://doi.org/10.1007/s10705 $-013-9581-x$

Chien, S. H., Prochnow, L. I., Tu, S., \& Snyder, C. S. (2011). Agronomic and environmental aspects of phosphate fertilizers varying in source and solubility: An update review. Nutrient Cycling in Agroecosystems, 89(2), 229-255. https://doi.org/10.1007/s10705-010-9390-4 
Cruz, C. D. (2013). GENES - A software package for analysis in experimental statistics and quantitative genetics. Acta Scientiarum. Agronomy, 35(3), 271-276. https://doi.org/10.4025/actasciagron.v35i3.21251

Dakora, F. D., \& Phillips, D. A. (2002). Root exudates as mediators of mineral acquisition in low-nutrient environments. Plant and Soil. https://doi.org/10.1023/A:1020809400075

Di, H. J., \& Cameron, K. C. (2004). Effects of temperature and application rate of a nitrification inhibitor, dicyandiamide (DCD), on nitrification rate and microbial biomass in a grazed pasture soil. Soil Research, 42(8), 927-932. Retrieved from https://doi.org/10.1071/SR04050

Ding, X., Fu, L., Liu, C., Chen, F., Hoffland, E., Shen, J., ... Feng, G. (2011). Positive feedback between acidification and organic phosphate mineralization in the rhizosphere of maize (Zea mays L.). Plant and Soil, 349(1-2), 13-24. https://doi.org/10.1007/s11104-011-0783-1

EMBRAPA. (1997). Manual de Métodos de Análise de Solo. Embrapa, 2(January 2016), 7-9.

Esteban, R., Ariz, I., Cruz, C., \& Moran, J. F. (2016). Review: Mechanisms of ammonium toxicity and the quest for tolerance. Plant Science, 248, 92-101. https://doi.org/https://doi.org/10.1016/j.plantsci.2016.04.008

FEBRAPDP/CONAB. (2012). Evolution of Cultivated Area in No-till System, Brazil. Retrieved July 4, 2016 , from http://febrapdp.org.br/download/PD_Brasil_2013.I.pdf

Gahoonia, T. S., Claassen, N., \& Jungk, A. (1992). Mobilization of phosphate in different soils by ryegrass supplied with ammonium or nitrate. Plant and Soil, 140(2), 241-248. https://doi.org/10.1007/BF00010600

Guppy, C. N., Menzies, N. W., Moody, P. W., \& Blamey, F. P. C. (2005). Competitive sorption reactions between phosphorus and organic matter in soil: A review. Australian Journal of Soil Research. https://doi.org/ 10.1071/SR04049

Gweyi-Onyango, J. P., Neumann, G., \& Romheld, V. (2005). The role of nitrogen forms on solubilisation and utilisation of rock phosphate by tomato plants. African Crop Science Conference Proceedings, 7, 1029-1032.

Haynes, R. J. (1990). Active ion uptake and maintenance of cation-anion balance: A critical examination of their role in regulating rhizosphere $\mathrm{pH}$. Plant and Soil, 126(2), 247-264. https://doi.org/10.1007/BF00012828

Hinsinger, P. (2001). Bioavailability of soil inorganic P in the rhizosphere as affected by root-induced chemical changes: A review. Plant and Soil, 237, 173-195). https://doi.org/10.1023/A:1013351617532

Hinsinger, P., \& Gilkes, R. J. (1996). Mobilization of phosphate from phosphate rock and alumina-sorbed phosphate by the roots of ryegrass and clover as related to rhizosphere pH. European Journal of Soil Science, 47(June), 533-544. https://doi.org/10.1111/j.1365-2389.1996.tb01853.x

Hinsinger, P., Plassard, C., Tang, C., \& Jaillard, B. (2003). Origins of root-mediated pH changes in the rhizosphere and their responses to environmental constraints: A review. Plant and Soil, 248(1), 43-59. https://doi.org/10.1023/A:1022371130939

Hoffmann, C., Ladewig, E., Claassen, N., \& Jungk, A. (1994). Phosphorus Uptake of Maize as Affected by Ammonium and Nitrate-Nitrogen-Measurements and Model-Calculations. Zeitschrift Fur Pflanzenernahrung Und Bodenkunde, 157(3), 225-232.

Hunt, J. F., Ohno, T., He, Z., Honeycutt, C. W., \& Dail, D. B. (2007). Inhibition of phosphorus sorption to goethite, gibbsite, and kaolin by fresh and decomposed organic matter. Biology and Fertility of Soils, 44(2), 277-288. https://doi.org/10.1007/s00374-007-0202-1

IFA. (2013). Direct application of phosphate rock (DAPR). Feeding the Earth, 4. Retrieved from http://www.fertilizer.org

International Plant Nutrition Institute, I. (2016). Evolução do consumo aparente de $N, P, K$ e total de NPK no Brasil.

Jing, J., Rui, Y., Zhang, F., Rengel, Z., \& Shen, J. (2010). Localized application of phosphorus and ammonium improves growth of maize seedlings by stimulating root proliferation and rhizosphere acidification. Field Crops Research, 119(2-3), 355-364. https://doi.org/10.1016/j.fcr.2010.08.005

Kant, S., Peng, M., \& Rothstein, S. J. (2011). Genetic regulation by NLA and microRNA827 for maintaining nitrate-dependent phosphate homeostasis in Arabidopsis. PLoS Genetics, 7(3). https://doi.org/10.1371/ journal.pgen.1002021

Kempers, A. J., \& Zweers, A. (1986). Ammonium determination in soil extracts by the salicylate method. 
Communications in Soil Science and Plant Analysis, 17(7), 715-723. https://doi.org/10.1080/0010362860 9367745

Khalil, M. I., Boeckx, P., Rosenani, A. B., \& Cleemput, O. Van. (2001). Nitrogen transformations and emission of greenhouse gases from three acid soils of humid tropics amended with $\mathrm{n}$ sources and moisture regime. II. Nitrous oxide and methane fluxes. Communications in Soil Science and Plant Analysis, 32(17-18), 2909-2924. https://doi.org/10.1081/CSS-120000971

Kronzucker, H. J., Britto, D. T., Davenport, R. J., \& Tester, M. (2001). Ammonium toxicity and the real cost of transport. Trends in Plant Science, 6(8), 335-337. https://doi.org/10.1016/S1360-1385(01)02022-2

Kronzucker, H. J., Siddiqi, M. Y., \& Glass, A. D. M. (1997). Conifer root discrimination against soil nitrate and the ecology of forest succession. Nature, 385(6611), 59-61. https://doi.org/10.1038/385059a0

Lambers, H., Shane, M. W., Cramer, M. D., Pearse, S. J., \& Veneklaas, E. J. (2006). Root structure and functioning for efficient acquisition of phosphorus: Matching morphological and physiological traits. Annals of Botany, 98(4), 693-713. https://doi.org/10.1093/aob/mcl114

Liebert, H., Griswold, J., \& Wilson III, I. (2015). Thinking Beyond Boundaries: Transnational Challenges to US Foreign Policy. Baltimore, MD, USA: JHU Press.

Liu, Y., \& von Wirén, N. (2017). Ammonium as a signal for physiological and morphological responses in plants. Journal of Experimental Botany, 68(10), 2581. https://doi.org/10.1093/jxb/erx086

Marcelino, R. (2009). Inibidor de nitrificação em fertilizantes nitrogenados e rendimento de milho. Instituto Agronômico de Campinas.

Morel, C., \& Hinsinger, P. (1999). Root-induced modifications of the exchange of phosphate ion between soil solution and soil solid phase. Plant and Soil, 211(1), 103-110. https://doi.org/10.1023/A:1004485432261

Novais, R. F., \& Smyth, T. J. (1999). Fósforo em solo e planta em condições tropicais (1st ed.). Viçosa, Brazil: Universidade Federal de Viçosa.

Ortas, I., Harris, P. J., \& Rowell, D. L. (1996). Enhancement uptake of phosphorus by mycorrhizal sorghum plants as influenced by forms of nitrogen. Plant and Soil, 184(2), 255-264. https://doi.org/10.1007/ BF00010454

Parfitt, R. L. (1979). The availability of P from phosphate-goethite bridging complexes. Desorption and uptake by ryegrass. Plant and Soil, 53(1), 55-65. https://doi.org/10.1007/BF02181879

Prochnow, L. I., Chien, S. H., Carmona, G., \& Henao, J. (2004). Greenhouse Evaluation of Phosphorus Sources Produced from a Low-Reactive Brazilian Phosphate Rock. Agronomy Journal, 96, 761-768. https://doi.org/ 10.2134/agronj2004.0761

R Development Core Team. (2016). R: A Language and Environment for Statistical Computing. R Foundation for Statistical Computing Vienna Austria. https://doi.org/10.1038/sj.hdy.6800737

Raij, B. van, Quaggio, J. A., \& Silva, N. M. da. (1986). Extraction of phosphorus, potassium, calcium, and magnesium from soils by an ion-exchange resin procedure.

Roy, E. D., Richards, P. D., Martinelli, L. A., Coletta, L. Della, Lins, S. R. M., Vazquez, F. F., ... Porder, S. (2016). The phosphorus cost of agricultural intensification in the tropics. Nature Plants, 2(5). https://doi.org/10.1038/NPLANTS.2016.43

Santos, L. P. D., Cunha, M. L. P., Clemente, J. M., Oliveira, T. F., de Aquino, P. M., Assunção, N. S., \& de Aquino, L. A. (2017). Recovery efficiencies of nitrogen, phosphorus and potassium of the garlic crop. Journal of Plant Nutrition, 40(5), 624-631. https://doi.org/10.1080/01904167.2016.1240201

Santos, W. O., Hesterberg, D., Mattiello, E. M., Vergütz, L., Barreto, M. S. C., Silva, I. R., \& Souza Filho, L. F. S. (2016). Increasing Soluble Phosphate Species by Treatment of Phosphate Rocks with Acidic Waste. Journal of Environment Quality, 45(6), 1988. https://doi.org/10.2134/jeq2016.03.0079

Sarasketa, A., González-Moro, M. B., González-Murua, C., \& Marino, D. (2014). Exploring ammonium tolerance in a large panel of Arabidopsis thaliana natural accessions. Journal of Experimental Botany, 65(20), 6023-6033. https://doi.org/10.1093/jxb/eru342

Sarkar, A. N., \& Wyn Jones, R. G. (1982). Influence of rhizosphere on the nutrient status of dwarf French beans. Plant and Soil, 64(3), 369-380. https://doi.org/10.1007/BF02372520

Schachtman, D. P., Reid, R. J., \& Ayling, S. M. (1998). Phosphorus Uptake by Plants: From Soil to Cell. Plant 
Physiology, 116, 447-453. https://doi.org/10.1104/pp.116.2.447

Teles, A. P. B., Rodrigues, M., Bejarano Herrera, W. F., Soltangheisi, A., Sartor, L. R., Withers, P. J. A., \& Pavinato, P. S. (2017). Do cover crops change the lability of phosphorus in a clayey subtropical soil under different phosphate fertilizers? Soil Use and Management, 33(1), 34-44. https://doi.org/10.1111/sum.12327

Villani, E. M. A., Barros, N. F., Novais, R. F., Costa, L. M., Neves, J. C. L., Alvarez V., V. H., \& Comerford, N. B. (1998). Phosphorus Diffusive Flux as Affected by Phosphate Source and Incubation Time. Soil Science Society of America Journal, 62(4), 1057-1061. https://doi.org/10.2136/sssaj1998.03615995006200040029x

Wang, X., Guppy, C. N., Watson, L., Sale, P. W. G., \& Tang, C. (2011). Availability of sparingly soluble phosphorus sources to cotton (Gossypium hirsutum L.), wheat (Triticum aestivum L.) and white lupin (Lupinus albus L.) with different forms of nitrogen as evaluated by a 32P isotopic dilution technique. Plant and Soil, 348(1), 85-98. https://doi.org/10.1007/s11104-011-0901-0

Withers, P. J. A., Rodrigues, M., Soltangheisi, A., De Carvalho, T. S., Guilherme, L. R. G., Benites, V. D. M., ... Pavinato, P. S. (2018). Transitions to sustainable management of phosphorus in Brazilian agriculture. Scientific Reports, 8(1). https://doi.org/10.1038/s41598-018-20887-z

Yang, J. E., Kim, J. J., Skogley, E. O., \& Schaff, B. E. (1998). A Simple Spectrophotometric Determination of Nitrate in Water, Resin, and Soil Extracts. Soil Science Society of America Journal, 62(4), 1108. https://doi.org/10.2136/sssaj1998.03615995006200040036x

Zeng, H., Liu, G., Kinoshita, T., Zhang, R., Zhu, Y., Shen, Q., \& Xu, G. (2012). Stimulation of phosphorus uptake by ammonium nutrition involves plasma membrane $\mathrm{H}+$ ATPase in rice roots. Plant and Soil, 357(1), 205-214. https://doi.org/10.1007/s11104-012-1136-4

Zhao, W., Cai, Z., \& Xu, Z. (2007). Does ammonium-based N addition influence nitrification and acidification in humid subtropical soils of China? Plant and Soil, 297(1), 213-221. https://doi.org/10.1007/s1110 4-007-9334-1

\section{Appendix A}

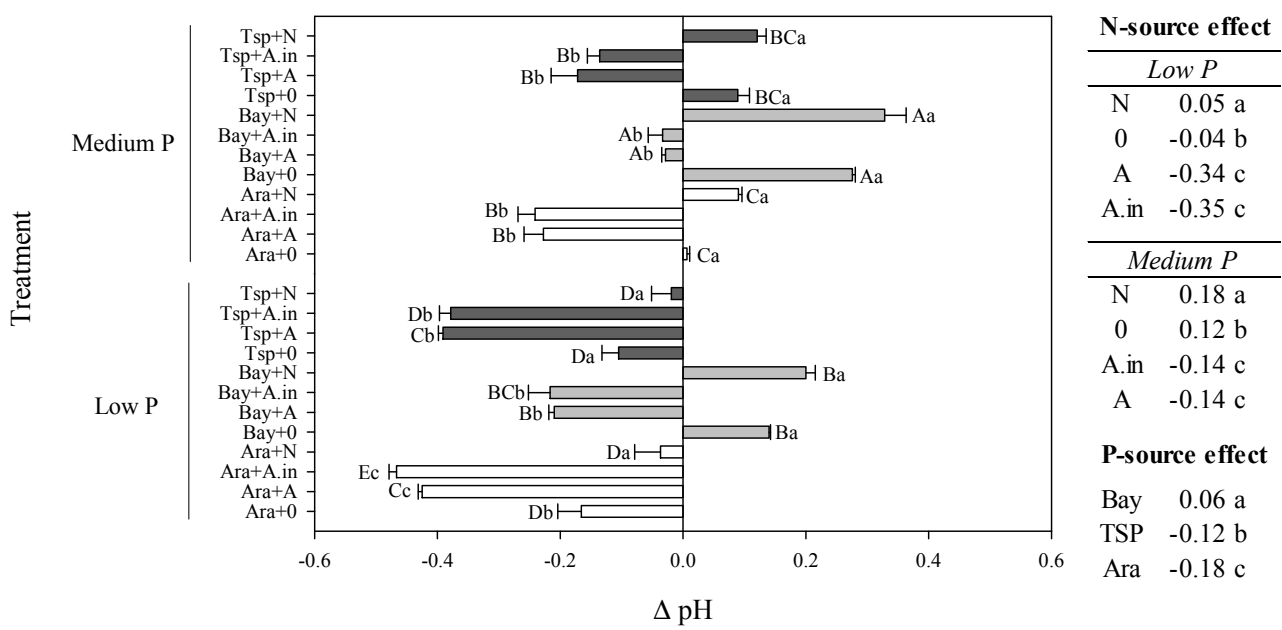

Figure A1. $\Delta \mathrm{pH}$ of millet rhizosphere soil cultivated under 24 different combinations of $\mathrm{P}$ and $\mathrm{N}$ sources, at low and medium initial P level. The factorial "P source $\times \mathrm{N}$ source" was splitted and shown in the figure. P sources:

Ara $=$ Araxá PR, Bay = Bayóvar PR, TSP $=$ triple superphosphate. $\mathrm{N}$ sources: $0=$ non-application of $\mathrm{N}, \mathrm{A}=$ ammonium sulfate, $\mathrm{A}$.in = ammonium sulfate with dicyandiamide (DCD) - a nitrification inhibitor agent, $\mathrm{N}=$ magnesium nitrate. Lowercase letters compare the $\mathrm{N}$ sources within the same $\mathrm{P}$ source. Means were compared by the Duncan test at $5 \%$ significance. The table on the right shows the interaction of "N source $\times \mathrm{P}$ initial level" and the effect of the $\mathrm{P}$ source on $\Delta \mathrm{pH}$ 


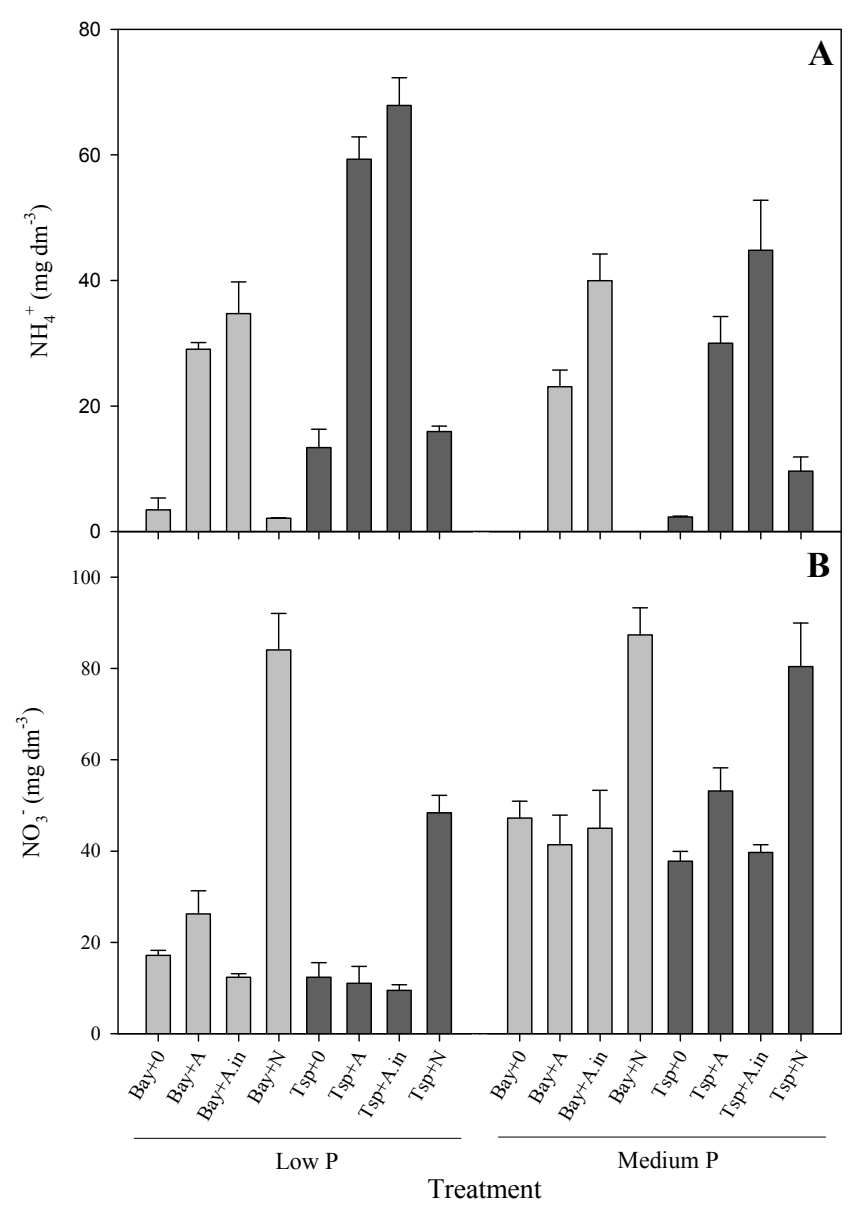

Figure A2. $\mathrm{NH}_{4}{ }^{+}$(A) and $\mathrm{NO}_{3}^{-}$(B) levels in oxisol treated with 16 different combinations of P (Bayóvar PR and TSP) and $\mathrm{N}$ sources, at low and medium initial $\mathrm{P}$ level

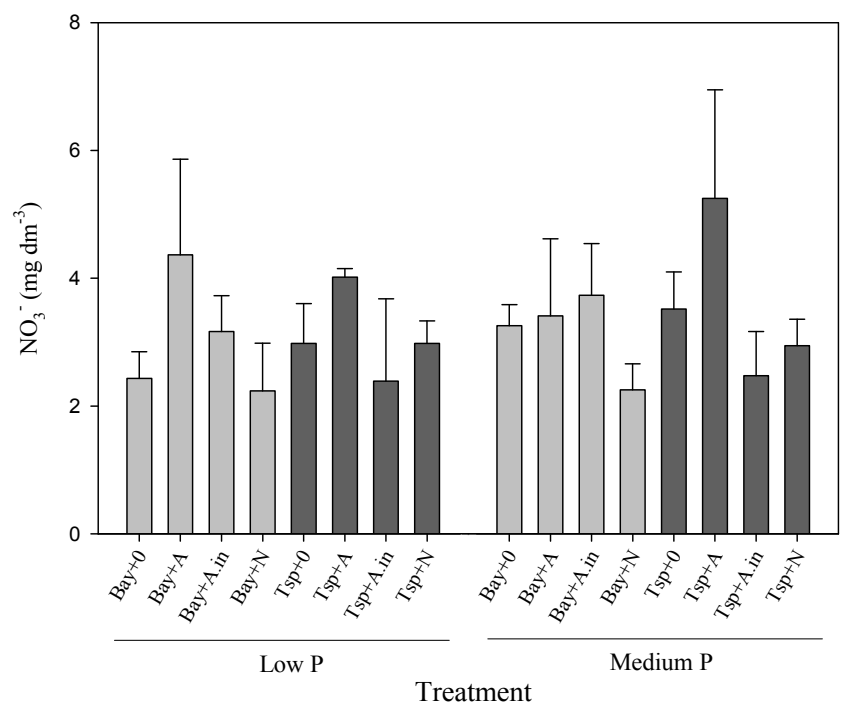

Figure $\mathrm{A} 3 . \mathrm{NO}_{3}{ }^{-}$in millet rhizosphere soil cultivated under 16 different combinations of $\mathrm{P}$ (Bayóvar PR and TSP) and $\mathrm{N}$ sources, at low and medium initial P level. $\mathrm{NH}_{4}{ }^{+}$was not detectable 

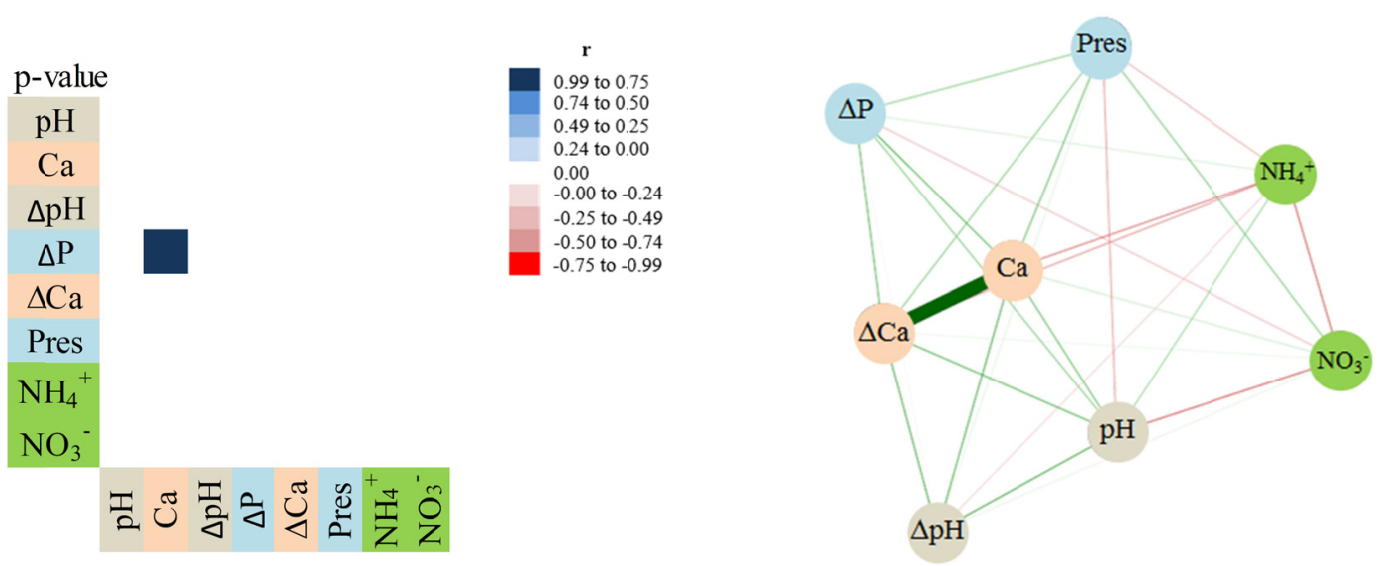

Figure A4. (A) Heat map of correlations between soil parameters of 24 combinations of P (Bayóvar PR, Araxá $\mathrm{PR}$ and TSP) and $\mathrm{N}\left(\mathrm{NH}_{4}{ }^{+}\right.$and $\mathrm{NO}_{3}{ }^{-}$sources) sources under different initial P level (P-low and P-medium) in the absence of plants. Each square represents significant correlation between the parameters heading the column with the parameters heading the row. Correlation coefficients and significances were calculated by Pearson correlations $(p<0.05)$. Blue and red squares represent positive and negative correlations, respectively; in addition, the correlation data were corrected by base FDR (Benjamini and Hochberg, 1995). (B) Correlation network of the same parameters evaluated. Red and green lines represent negative and positive correlations, respectively. Line width is proportional to the strength of the correlation

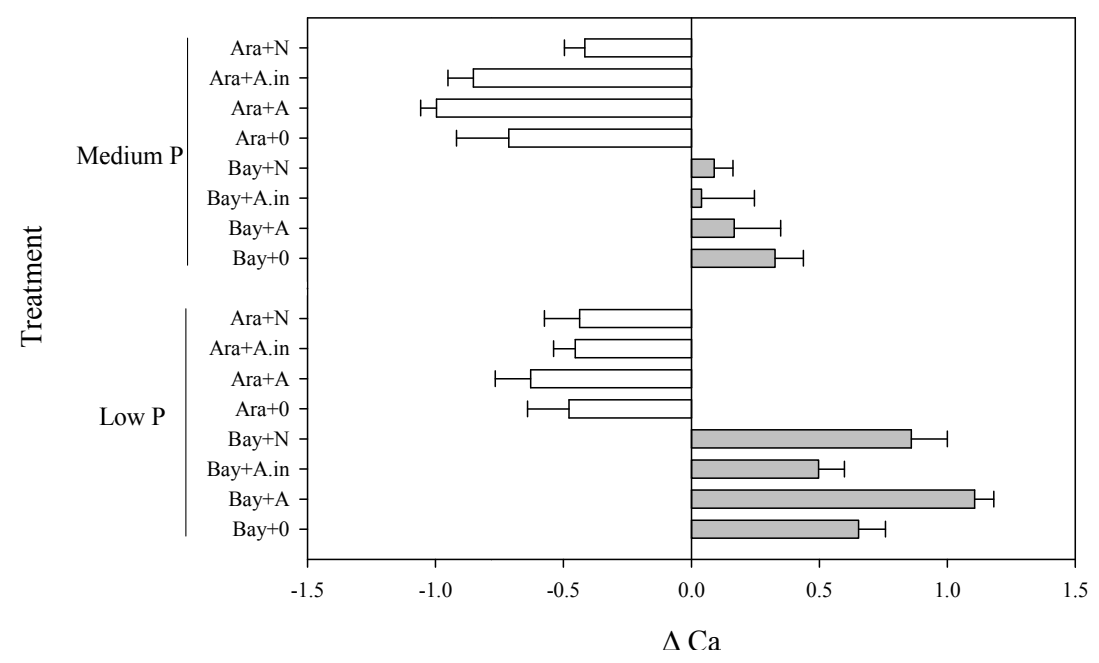

Figure A5. $\triangle \mathrm{Ca}$ of millet rhizosphere soil cultivated under 16 different combinations of PR and $\mathrm{N}$ sources, at low and medium $\mathrm{P}$ level in the absence of plants. P sources: Ara = Araxá PR, Bay = Bayóvar PR, TSP $=$ triple superphosphate. $\mathrm{N}$ sources: $0=$ non-application of $\mathrm{N}, \mathrm{A}=$ ammonium sulfate, $\mathrm{A}$.in = ammonium sulfate with dicyandiamide (DCD) - a nitrification inhibitor agent, $\mathrm{N}=$ magnesium nitrate 


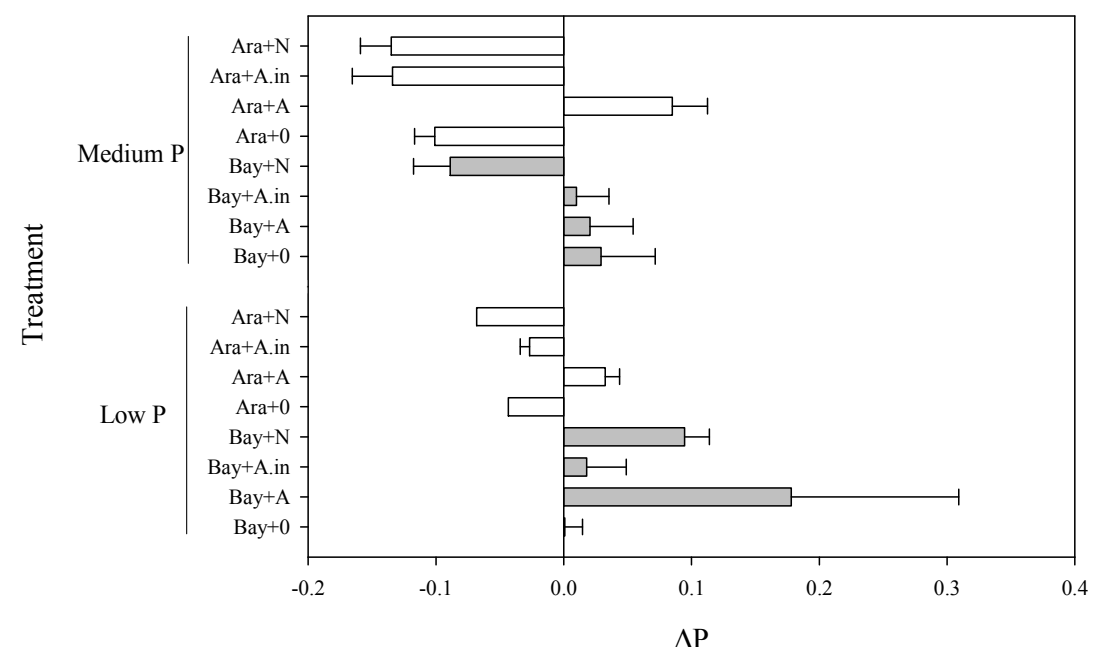

Figure A6. $\Delta \mathrm{P}$ of millet rhizosphere soil cultivated under 16 different combinations of $\mathrm{PR}$ and $\mathrm{N}$ sources, at low and medium initial P level in the absence of plants. P sources: Ara = Araxá PR, Bay = Bayóvar PR, TSP = triple superphosphate. $\mathrm{N}$ sources: $0=$ non-application of $\mathrm{N}, \mathrm{A}=$ ammonium sulfate, $\mathrm{A}$.in $=$ ammonium sulfate with dicyandiamide (DCD) - a nitrification inhibitor agent, $\mathrm{N}=$ magnesium nitrate

Table A1. Loading factors of the principal components that best separate the data. PC1 and PC2 model 52.1\% and $21.4 \%$ of the data matrix variance, respectively. The variables were ordered from the highest to the lowest values

\begin{tabular}{|c|c|c|c|}
\hline \multicolumn{2}{|c|}{ PC1 } & \multicolumn{2}{|c|}{ PC2 } \\
\hline Variable & Loading factor & Variable & Loading factor \\
\hline $\mathrm{P}$ (root) & 0.397 & $\Delta \mathrm{pH}$ & 0.611 \\
\hline Recovery rate (\%) & 0.375 & $\mathrm{pH}$ & 0.549 \\
\hline $\mathrm{P}$ (shoot) & 0.36 & $\mathrm{Ca}$ (soil) & 0.305 \\
\hline $\mathrm{Ca}$ (shoot) & 0.357 & $\mathrm{Ca}$ (root) & 0.234 \\
\hline P res (soil) & 0.349 & P res (soil) & 0.202 \\
\hline DW (root) & 0.303 & $\mathrm{P}$ (shoot) & 0.021 \\
\hline $\mathrm{Ca}$ (root) & 0.274 & Recovery rate $(\%)$ & 0.017 \\
\hline $\mathrm{Ca}$ (soil) & 0.256 & $\mathrm{P}$ (root) & -0.002 \\
\hline DW (shoot) & 0.255 & $\mathrm{Ca}$ (shoot) & -0.024 \\
\hline$\Delta \mathrm{pH}$ & 0.023 & DW (root) & -0.234 \\
\hline $\mathrm{pH}$ & -0.161 & DW (shoot) & -0.283 \\
\hline
\end{tabular}

\section{Copyrights}

Copyright for this article is retained by the author(s), with first publication rights granted to the journal.

This is an open-access article distributed under the terms and conditions of the Creative Commons Attribution license (http://creativecommons.org/licenses/by/4.0/). 